\title{
Absence of Reverse Anomeric Effect in
}

\section{Furanosides.}

Hans Grundberg, Johan Eriksson-Bajtner, Karl-Erik Bergquist, Anders Sundin and Ulf

\section{Ellervik $^{*}$}

Organic Chemistry, Lund University, P.O. Box 124, SE-221 00 Lund, Sweden,

ulf.ellervik@organic.lu.se

\section{Supporting information}

General experimental conditions

Molecular modeling of a methylamino analog of compound $2 \quad$ S3

${ }^{1} \mathrm{H}-\mathrm{NMR}$ for compound $\mathbf{2}$

S5

${ }^{1} \mathrm{H}-\mathrm{NMR}$ for compound $\mathbf{3}$

S6

${ }^{1} \mathrm{H}-\mathrm{NMR}$ for compound 4

Data for titration of compound 2

Data for titration of compound $\mathbf{3}$

Data for titration of compound 4

S8

Experimental conditions for the NOESY experiment and T1 measurement

S9

Evaluation of NOESY spectra

S10

NOESY data for compound $\mathbf{2}$

S11

\footnotetext{
*ulf.ellervik@organic.lu.se
} 


\section{General experimental conditions.}

The structures of all new compounds were determined by NMR analysis, including COSY, NOESY and HETCOR. Chemical shifts are given in ppm downfield from the signal for $\mathrm{Me}_{4} \mathrm{Si}$, with $\mathrm{CHCl}_{3}$ as an internal reference. Melting points are uncorrected. $\mathrm{CH}_{2} \mathrm{Cl}_{2}$ was dried by distillation from $\mathrm{CaH}_{2}$ and bromine was distilled from $\mathrm{P}_{2} \mathrm{O}_{5}$. Column chromatography was performed on $\mathrm{SiO}_{2}$ and $\mathrm{Al}_{2} \mathrm{O}_{3}$ (active neutral, grade I). Preparative, centrifugally accelerated, radial thin layer chromatography separation was performed with the rotor covered with a $1 \mathrm{~mm}$ layer of silica gel. 
Molecular modeling of a methylamino analog of compound 2

\begin{tabular}{|c|c|c|c|c|c|}
\hline \multicolumn{2}{|c|}{$\begin{array}{l}\text { Conformation QM Method at the 6- } \\
\qquad 31 \mathrm{~g}^{* *+}+\text { level }\end{array}$} & QM Energy & $\begin{array}{l}\text { Solvation } \\
\text { Energy }\end{array}$ & $\begin{array}{l}\text { Solution Phase } \\
\text { Energy }\end{array}$ & $\begin{array}{l}\Delta \mathrm{E} \text { ax to eq in } \mathrm{gf} \\
\text { and solvated }\end{array}$ \\
\hline peq1-gf & DFT(b3lyp) & -560.610173 & & & \\
\hline pax1-gf & DFT(b3lyp) & -560.608343 & & & \\
\hline peq2-gf & DFT(b3lyp) & -560.612730 & & & 0.662022 \\
\hline $\operatorname{pax} 2-g f$ & DFT(b3lyp) & -560.611675 & & & \\
\hline peq1 & DFT(b3lyp)/SOLV & -560.615254 & -0.005103 & -560.615254 & \\
\hline $\operatorname{pax} 1$ & DFT(b3lyp)/SOLV & -560.614051 & -0.005680 & -560.614051 & \\
\hline peq2 & DFT(b3lyp)/SOLV & -560.617722 & -0.004966 & -560.617722 & 0.660139 \\
\hline $\operatorname{pax} 2$ & DFT(b3lyp)/SOLV & -560.616670 & -0.004994 & -560.616670 & \\
\hline
\end{tabular}

pax-conformation coordinates

\begin{tabular}{|c|c|c|c|}
\hline & y & $\mathrm{z}$ & \\
\hline $\mathrm{C} 1$ & 1.932 & -1.589 & -0.074 \\
\hline $\mathrm{C} 2$ & 2.633 & -0.384 & -0.786 \\
\hline $\mathrm{C} 3$ & 1.842 & 0.836 & -0.258 \\
\hline $\mathrm{C} 4$ & 0.89 & -0.897 & 0.842 \\
\hline $\mathrm{C} 5$ & 0.383 & 0.835 & -0.82 \\
\hline C6 & -0.432 & 2.053 & -0.303 \\
\hline $\mathrm{C} 7$ & -0.269 & -0.378 & -0.047 \\
\hline $\mathrm{C} 8$ & -1.456 & 0.22 & 0.735 \\
\hline C9 & 1.629 & 0.41 & 1.214 \\
\hline O1 & -1.158 & 1.633 & 0.856 \\
\hline N1 & -2.722 & -0.074 & 0.102 \\
\hline $\mathrm{C} 10$ & -3.893 & 0.54 & 0.736 \\
\hline C11 & 0.291 & 0.755 & -2.35 \\
\hline $\mathrm{H} 1$ & 3.68 & -0.301 & -0.475 \\
\hline $\mathrm{H} 2$ & 2.633 & -0.469 & -1.875 \\
\hline $\mathrm{H} 3$ & 2.647 & -2.168 & 0.521 \\
\hline $\mathrm{H} 4$ & 1.461 & -2.283 & -0.779 \\
\hline H5 & 2.354 & 1.791 & -0.417 \\
\hline H6 & -0.63 & -1.165 & -0.718 \\
\hline $\mathrm{H} 7$ & 2.573 & 0.23 & 1.742 \\
\hline H8 & 1.022 & 1.105 & 1.797 \\
\hline H9 & -1.128 & 2.412 & -1.076 \\
\hline $\mathrm{H} 10$ & 0.201 & 2.896 & -0.006 \\
\hline H11 & -2.695 & 0.14 & -0.892 \\
\hline $\mathrm{H} 12$ & -3.974 & 0.179 & 1.767 \\
\hline H13 & -4.796 & 0.229 & 0.202 \\
\hline
\end{tabular}




$\begin{array}{lrrr}\text { H14 } & -3.86 & 1.638 & 0.764 \\ \text { H15 } & -1.514 & -0.139 & 1.769 \\ \text { H16 } & 0.554 & -1.521 & 1.675 \\ \text { H17 } & -0.756 & 0.77 & -2.677 \\ \text { H18 } & 0.792 & 1.611 & -2.819 \\ \text { H19 } & 0.742 & -0.156 & -2.752\end{array}$

peq-conformation coordinates

\begin{tabular}{|c|c|c|c|}
\hline $\mathrm{X}$ & y & z & \\
\hline $\mathrm{C} 1$ & 1.932 & -1.588 & -0.074 \\
\hline $\mathrm{C} 2$ & 2.63 & -0.382 & -0.788 \\
\hline $\mathrm{C} 3$ & 1.841 & 0.84 & -0.257 \\
\hline $\mathrm{C} 4$ & 0.886 & -0.9 & 0.843 \\
\hline C5 & 0.387 & 0.829 & -0.821 \\
\hline C6 & -0.462 & 2.035 & -0.336 \\
\hline $\mathrm{C} 7$ & -0.266 & -0.374 & -0.046 \\
\hline $\mathrm{C} 8$ & -1.474 & 0.226 & 0.707 \\
\hline C9 & 1.627 & 0.406 & 1.213 \\
\hline $\mathrm{O} 1$ & -1.73 & 1.498 & 0.043 \\
\hline N1 & -2.63 & -0.616 & 0.708 \\
\hline $\mathrm{C} 10$ & -3.789 & -0.104 & 1.448 \\
\hline C11 & 0.275 & 0.711 & -2.348 \\
\hline H1 & 3.679 & -0.302 & -0.482 \\
\hline $\mathrm{H} 2$ & 2.624 & -0.466 & -1.877 \\
\hline $\mathrm{H} 3$ & 2.649 & -2.166 & 0.519 \\
\hline $\mathrm{H} 4$ & 1.462 & -2.282 & -0.78 \\
\hline H5 & 2.355 & 1.795 & -0.41 \\
\hline H6 & -0.628 & -1.153 & -0.728 \\
\hline $\mathrm{H} 7$ & 0.549 & -1.524 & 1.676 \\
\hline H8 & 2.569 & 0.229 & 1.744 \\
\hline H9 & 1.028 & 1.101 & 1.807 \\
\hline H10 & -0.636 & 2.778 & -1.12 \\
\hline H11 & 0.007 & 2.546 & 0.518 \\
\hline H12 & -2.89 & -0.852 & -0.248 \\
\hline H13 & -3.507 & 0.055 & 2.494 \\
\hline H14 & -4.587 & -0.852 & 1.43 \\
\hline H15 & -4.186 & 0.842 & 1.054 \\
\hline H16 & -1.222 & 0.444 & 1.757 \\
\hline H17 & -0.774 & 0.792 & -2.655 \\
\hline H18 & 0.833 & 1.513 & -2.848 \\
\hline H19 & 0.651 & -0.246 & -2.725 \\
\hline
\end{tabular}




\section{${ }^{1}$ H-NMR of compound 2.}

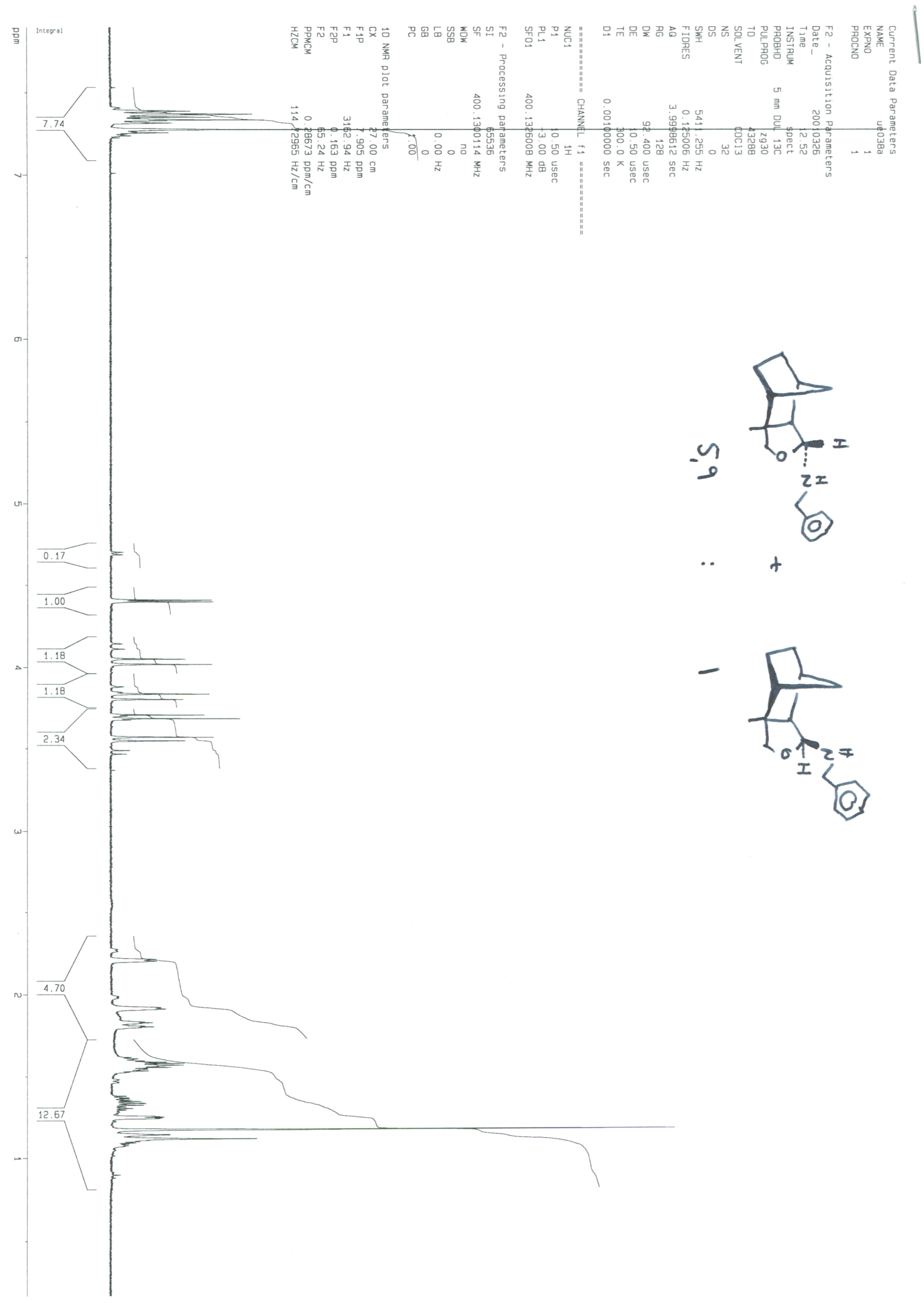


${ }^{1} \mathrm{H}-\mathrm{NMR}$ of compound 3 .

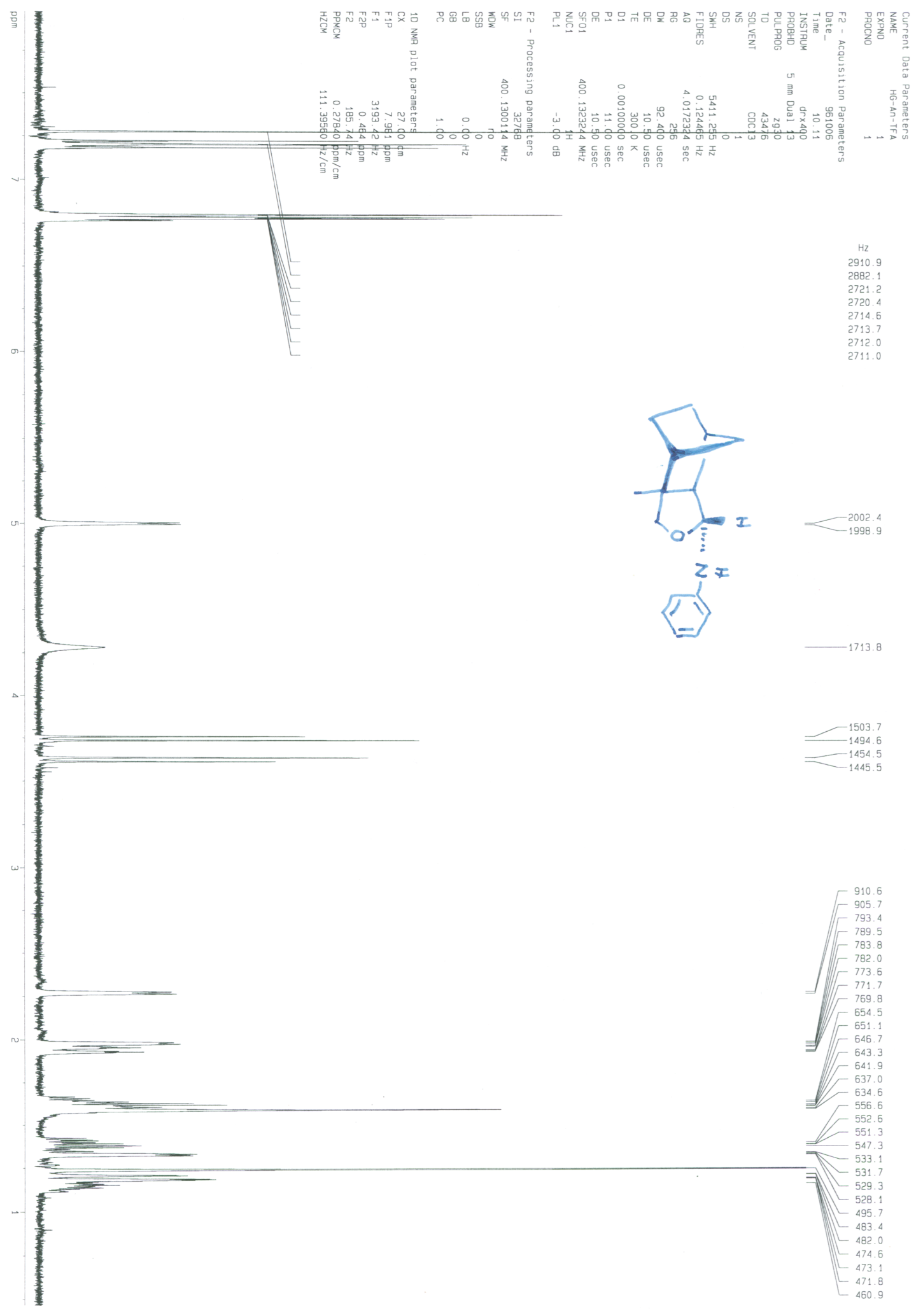


${ }^{1} \mathrm{H}$-NMR of compound 4 .

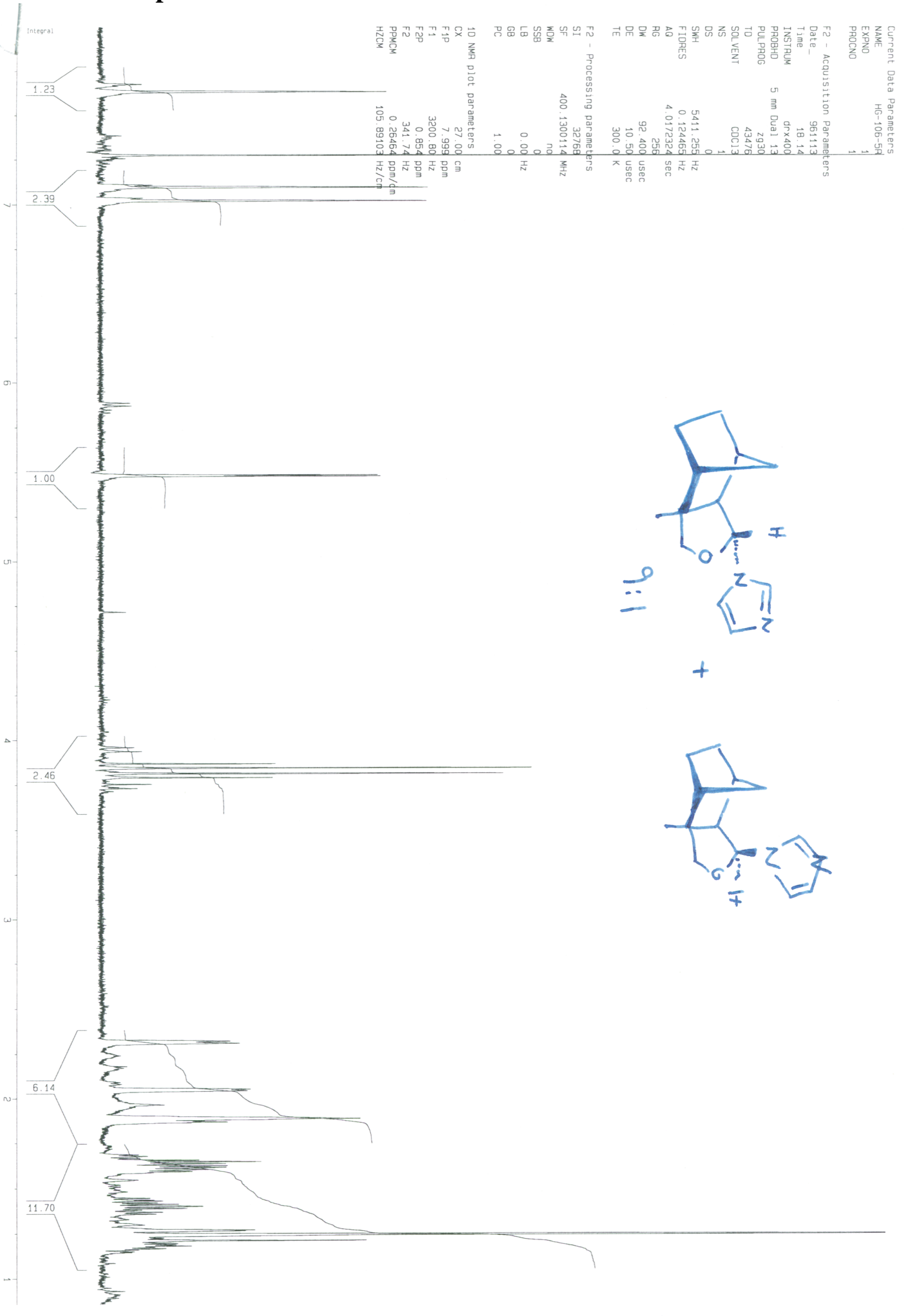




\section{Data for titration of compound 2.}

\begin{tabular}{cccccc}
\hline $\begin{array}{c}\text { TfOH } \\
(\text { eq. })\end{array}$ & $\begin{array}{c}J_{\mathrm{H} 5-\mathrm{H} 6} \\
(\operatorname{exp~1)}\end{array}$ & $\begin{array}{c}J_{\mathrm{H} 5-\mathrm{H} 6} \\
(\exp 3)\end{array}$ & $\begin{array}{c}J_{\mathrm{H} 5-\mathrm{H} 6} \\
(\exp 3)\end{array}$ & $\begin{array}{c}J_{\mathrm{H} 5-\mathrm{H} 6} \\
\text { (average) }\end{array}$ & $\begin{array}{c}\text { Standard } \\
\text { deviation }\end{array}$ \\
\hline 0 & 4.21 & 4.13 & 4.21 & 4.18 & 0.05 \\
0.1 & 3.88 & 3.96 & 3.96 & 3.93 & 0.05 \\
0.2 & 3.55 & 3.63 & 3.72 & 3.63 & 0.09 \\
0.3 & 3.47 & 3.47 & 3.47 & 3.47 & 0.00 \\
0.4 & 3.22 & 3.22 & 3.22 & 3.22 & 0.00 \\
0.5 & 2.97 & 2.89 & 2.97 & 2.94 & 0.05 \\
0.6 & 2.81 & 2.72 & 2.72 & 2.75 & 0.05 \\
0.7 & 2.56 & 2.48 & 2.48 & 2.51 & 0.05 \\
0.8 & 2.39 & 2.23 & 2.23 & 2.28 & 0.09 \\
0.9 & 2.23 & 2.06 & 1.98 & 2.09 & 0.13 \\
1 & 1.98 & 1.73 & 1.73 & 1.81 & 0.14 \\
\hline
\end{tabular}

\section{Data for titration of compound 3.}

\begin{tabular}{ccccccc}
\hline $\begin{array}{c}\text { TfOH } \\
\text { (eq.) }\end{array}$ & $\begin{array}{c}J_{\mathrm{H} 5-\mathrm{H} 6} \\
(\exp 1)\end{array}$ & $\begin{array}{c}J_{\mathrm{H} 5-\mathrm{H} 6} \\
(\exp 2)\end{array}$ & $\begin{array}{c}J_{\mathrm{H} 5-\mathrm{H} 6} \\
(\exp 3)\end{array}$ & $\begin{array}{c}J_{\mathrm{H} 5-\mathrm{H} 6} \\
(\exp 4)\end{array}$ & $\begin{array}{c}J_{\mathrm{H} 5-\mathrm{H} 6} \\
(\text { average })\end{array}$ & $\begin{array}{c}\text { Standard } \\
\text { deviation }\end{array}$ \\
\hline 0 & 3.80 & 3.80 & 3.80 & 3.80 & 3.80 & 0.00 \\
0.1 & 3.63 & 3.55 & 3.63 & 3.63 & 3.61 & 0.04 \\
0.2 & 3.47 & 3.39 & bs & 3.39 & 3.42 & 0.05 \\
0.3 & 3.06 & 3.14 & 2.97 & bs & 3.06 & 0.09 \\
0.4 & 2.64 & 2.64 & 2.56 & 2.56 & 2.60 & 0.05 \\
0.5 & 2.48 & 2.48 & 2.48 & 2.48 & 2.48 & 0.00 \\
0.6 & 2.31 & bs & 2.39 & 2.31 & 2.34 & 0.05 \\
\hline
\end{tabular}

\section{Data for titration of compound 4.}

\begin{tabular}{cccccc}
\hline $\begin{array}{c}\text { TfOH } \\
\text { (eq.) }\end{array}$ & $\begin{array}{c}J_{\mathrm{H} 5-\mathrm{H} 6} \\
(\operatorname{exp~1)}\end{array}$ & $\begin{array}{c}J_{\mathrm{H} 5-\mathrm{H} 6} \\
(\operatorname{exp~3)}\end{array}$ & $\begin{array}{c}J_{\mathrm{H} 5-\mathrm{H} 6} \\
(\operatorname{exp~3)})\end{array}$ & $\begin{array}{c}J_{\mathrm{H} 5-\mathrm{H} 6} \\
\text { (average) }\end{array}$ & $\begin{array}{c}\text { Standard } \\
\text { deviation }\end{array}$ \\
\hline 0 & 2.48 & 2.48 & 2.48 & 2.48 & 0.00 \\
0.1 & 2.39 & bs & 2.39 & 2.39 & 0.00 \\
0.2 & 2.15 & 2.23 & 2.15 & 2.18 & 0.05 \\
0.3 & 2.06 & 2.06 & 2.06 & 2.06 & 0.00 \\
0.4 & 1.98 & 1.98 & 1.98 & 1.98 & 0.00 \\
0.5 & 1.90 & 1.90 & bs & 1.90 & 0.00 \\
\hline
\end{tabular}

bs $=$ broad singlett 


\section{Experimental conditions for the NOESY experiment and T1 measurement}

The collection of data was performed on a Bruker Avance 500MHz NMR spectrometer operated with the XWINNMR rev.2.6 software. Sample temperature was $25^{\circ} \mathrm{C}$ and optimization of tuning and matching was done for each sample. The NOESY spectra were collected with the TPPI method using $2 \mathrm{k} \times 256$ data points. A sweep width of 5000 $\mathrm{Hz}$ resulted in $205 \mathrm{~ms}$ acquisition time. We chose a relatively long mixing time of $1 \mathrm{~s}$ in order to achieve a good $\mathrm{S} / \mathrm{N}$ for the correlations. The relaxation time was kept short, $2 \mathrm{~s}$, in order to complete the experiment within a limited experimental time. Thus the overall repetition time was approximately $3.3 \mathrm{~s}$ and taken together with the number of repetitions used, 64, resulted in a total experimental time of $15 \mathrm{~h}$. Data were transformed with zero filling to $4 \mathrm{kx} 1 \mathrm{k}$, without linear prediction and after application of a $90^{\circ}$ shifted sine-bell apodization function. The diagonal was phased into the negative direction and the correlations positive. Base line correction was applied in both dimensions using a 5th order polynomial correction. Volume integrations were performed over peak area presented at one the same absolute threshold value throughout the series of NOESY spectra. Transformation and integration were done using the Bruker TOPSPIN rev.1.3 software. A T1 measurement was performed using the inversion-recovery technique applied with a non-selective pulse. Collection of data as well as the calculation of T1 was performed using the Bruker XWINNMR rev.2.6 software. T1 relaxation times for a sample of compound 2 in $\mathrm{CDCl} 3$ before the addition of TFA were found to be $3.2 \mathrm{~s}$ for $\mathrm{H}_{1}, 2.1 \mathrm{~s}$ for $\mathrm{H}_{3 \mathrm{a}}, 2.9 \mathrm{~s}$ for $\mathrm{H}_{5}, 2.3 \mathrm{~s}$ for $\mathrm{H}_{6}, 3.1 \mathrm{~s}$ for $\mathrm{H}_{7}$ and $1.5 \mathrm{~s}$ for $\mathrm{H}_{10 \mathrm{a}}$. 


\section{Evaluation of NOESY spectra}

The volume integrals of NOESY correlation peaks were normalized to the correlation $\mathrm{H}_{10 \mathrm{a}}-\mathrm{H}_{10 \mathrm{~b}}$ which was set to a value of 100 in each spectra. The correlation for which the chemical shift in F1 is the same as the diagonal peak of $\mathrm{H}_{10 \mathrm{~b}}$ was used. Deviation in volume integral between the two correlation peaks of $\mathrm{H}_{10 \mathrm{a}}$ and $\mathrm{H}_{10 \mathrm{~b}}$ were less than 5\%. The NOESY spectra were not symmetrical, as regarding the intensities of correlations, and this was expected to arise from differences in relaxationtimes $\mathrm{T} 1$ between the correlating protons in combination with the relatively short repetition time for the experiment, $3.3 \mathrm{~s}$. For diagrammatic representation of qualitative variations of NOE interactions we chose to compare the volume integrals from the F2 chemical shift of $\mathrm{H}_{3 \mathrm{a}}$ and $\mathrm{H}_{5}$ throughout the experimental series of three NOESY spectra. We have used the convention of labeling correlations with "F2-shift to F1-shift" such that the correlation of $\mathrm{H}_{3 \mathrm{a}}-\mathrm{H}_{1}$ is at the chemical shift of $\mathrm{H}_{3 \mathrm{a}}$ in F2 and at the chemical shift of $\mathrm{H}_{1}$ in the F1dimension. The qualitative results for the interactions between $\mathrm{H}_{3 \mathrm{a}}-\mathrm{H}_{1}, \mathrm{H}_{5}-\mathrm{H}_{6}$ and $\mathrm{H}_{5}-\mathrm{H}_{7}$ are the same as for $\mathrm{H}_{1}-\mathrm{H}_{3 a}, \mathrm{H}_{6}-\mathrm{H}_{5}$ and $\mathrm{H}_{7}-\mathrm{H}_{5}$. However, we found that the integrals of correlations $\mathrm{H}_{10 \mathrm{a}}-\mathrm{H}_{3 \mathrm{a}}$ and $\mathrm{H}_{10 \mathrm{a}}-\mathrm{H}_{5}$, were almost constant throughout the series, in contrast to the clear effect of reduction of integral on $\mathrm{H}_{3 \mathrm{a}}-\mathrm{H}_{10 \mathrm{a}}$ and $\mathrm{H}_{5}-\mathrm{H}_{10 \mathrm{a}}$. These deviations from symmetry in response at the $\mathrm{F} 2$ chemical shift of $\mathrm{H}_{10 \mathrm{a}}$ may be explained to arise from large differences in $\mathrm{T} 1$ in combination with the relative short repetition time for the experiment. 
NOESY data for compound 2.

NOESY correlations, (volume int.), normalized to the correlation of $\mathrm{H}_{10 \mathrm{a}}$ to $\mathrm{H}_{10 \mathrm{~b}}$

\begin{tabular}{|c|c|c|c|c|}
\hline $\begin{array}{l}\text { \# Ekvivalents } \\
\text { of TFA }\end{array}$ & Integral & $\begin{array}{c}\text { H-label } \\
{[\mathrm{F} 2]}\end{array}$ & $\begin{array}{c}\text { H-label } \\
{[\mathrm{F} 1]}\end{array}$ & $\begin{array}{l}\text { NOESY correlation } \\
\text { (normalized) }\end{array}$ \\
\hline $0.0 \mathrm{ekv}$ & 435364740 & 1 & $3 a$ & 14.1 \\
\hline $0.5 \mathrm{ekv}$ & 638205196 & 1 & $3 a$ & 17.2 \\
\hline $1.0 \mathrm{ekv}$ & 779451792 & 1 & $3 a$ & 19.5 \\
\hline $0.0 \mathrm{ekv}$ & 319625566 & $3 a$ & 1 & 10.4 \\
\hline $0.5 \mathrm{ekv}$ & 484589288 & $3 a$ & 1 & 13.0 \\
\hline $1.0 \mathrm{ekv}$ & 653730256 & $3 a$ & 1 & 16.4 \\
\hline $0.0 \mathrm{ekv}$ & 70881272 & 5 & 6 & 2.3 \\
\hline $0.5 \mathrm{ekv}$ & 164431924 & 5 & 6 & 4.4 \\
\hline $1.0 \mathrm{ekv}$ & 226087328 & 5 & 6 & 5.7 \\
\hline $0.0 \mathrm{ekv}$ & 60659924 & 6 & 5 & 2.0 \\
\hline $0.5 \mathrm{ekv}$ & 126093108 & 6 & 5 & 3.4 \\
\hline $1.0 \mathrm{ekv}$ & 203509928 & 6 & 5 & 5.1 \\
\hline $0.0 \mathrm{ekv}$ & 180726464 & 5 & 7 & 5.9 \\
\hline $0.5 \mathrm{ekv}$ & 366995908 & 5 & 7 & 9.9 \\
\hline $1.0 \mathrm{ekv}$ & 551014828 & 5 & 7 & 13.8 \\
\hline $0.0 \mathrm{ekv}$ & 213428228 & 7 & 5 & 6.9 \\
\hline $0.5 \mathrm{ekv}$ & 376223884 & 7 & 5 & 10.2 \\
\hline $1.0 \mathrm{ekv}$ & 595665112 & 7 & 5 & 14.9 \\
\hline $0.0 \mathrm{ekv}$ & 555488072 & 5 & $10 \mathrm{a}$ & 18.0 \\
\hline $0.5 \mathrm{ekv}$ & 612680800 & 5 & $10 \mathrm{a}$ & 16.5 \\
\hline $1.0 \mathrm{ekv}$ & 562190524 & 5 & $10 \mathrm{a}$ & 14.1 \\
\hline $0.0 \mathrm{ekv}$ & 356748852 & $10 \mathrm{a}$ & 5 & 11.6 \\
\hline $0.5 \mathrm{ekv}$ & 406862388 & $10 \mathrm{a}$ & 5 & 11.0 \\
\hline $1.0 \mathrm{ekv}$ & 459558548 & $10 \mathrm{a}$ & 5 & 11.5 \\
\hline $0.0 \mathrm{ekv}$ & 519334278 & $3 a$ & $10 \mathrm{a}$ & 16.8 \\
\hline $0.5 \mathrm{ekv}$ & 554038444 & $3 a$ & $10 \mathrm{a}$ & 14.9 \\
\hline $1.0 \mathrm{ekv}$ & 526633308 & $3 a$ & $10 \mathrm{a}$ & 13.2 \\
\hline $0.0 \mathrm{ekv}$ & 364021456 & $10 \mathrm{a}$ & $3 a$ & 11.8 \\
\hline $0.5 \mathrm{ekv}$ & 450452920 & $10 \mathrm{a}$ & $3 a$ & 12.2 \\
\hline $1.0 \mathrm{ekv}$ & 499959120 & $10 \mathrm{a}$ & $3 a$ & 12.5 \\
\hline
\end{tabular}




$\begin{array}{lrccc}0.0 \mathrm{ekv} & 39923696 & 3 \mathrm{a} & 5 & 1.3 \\ 0.5 \mathrm{ekv} & 47120688 & 3 \mathrm{a} & 5 & 1.3 \\ 1.0 \mathrm{ekv} & 56006608 & 3 \mathrm{a} & 5 & 1.4 \\ 0.0 \mathrm{ekv} & 73920552 & 5 & 3 \mathrm{a} & 2.4 \\ 0.5 \mathrm{ekv} & 111179536 & 5 & 3 \mathrm{a} & 3.0 \\ 1.0 \mathrm{ekv} & 80950624 & 5 & 3 \mathrm{a} & 2.0 \\ & & & & \\ 0.0 \mathrm{ekv} & 93891320 & 6 & 7 & 3.0 \\ 0.5 \mathrm{ekv} & 190782068 & 6 & 7 & 5.1 \\ 0.0 \mathrm{ekv} & 127539024 & 7 & 6 & 4.1 \\ 0.5 \mathrm{ekv} & 259511156 & 7 & 6 & 100.0 \\ & & & & 100.0 \\ 0.0 \mathrm{ekv} & 3083964936 & 10 \mathrm{a} & 10 \mathrm{~b} & 100.0 \\ 0.5 \mathrm{ekv} & 3706107500 & 10 \mathrm{a} & 10 \mathrm{~b} & \\ 1.0 \mathrm{ekv} & 3997433504 & 10 \mathrm{a} & 10 \mathrm{~b} & \end{array}$

